\title{
ANTI HBS TITRE; AMONG OUTGOING FINAL YEAR MBBS STUDENTS
}

1. MBBS.

WMO Eye Department Allied Hospital Faisalabad.

2. MBBS, FCPS.

Department of Ophthalmology, Allied Hospital Faisalabad.

3. MBBS,

4. MBBS, M.Phil.

Professor Biochemistry, Independent Medical College, Faisalabad.

Correspondence Address: Dr. Muhammad Ashraf MBBS, M.Phil

Professor Biochemistry, Independent Medical College,

Faisalabad.

ashrafbiopmc@yahoo.com

Article received on: 30/03/2017

Accepted for publication: 25/06/2017

Received after proof reading: 08/08/2017
Nahdia Ashraf ${ }^{1}$, Muhammad Usman Hussain ${ }^{2}$, Iqra Qamar ${ }^{3}$, Muhammad Ashraf ${ }^{4}$

ABSTRACT... Introduction: The doctors and paramedical staff are at high risk of developing Hepatitis $B$, infection. Hepatitis $B$ vaccine is mandatory for medical students prior to admission in medical colleges. After completion of vaccination determination of anti HBS is not in practice. All over the world some people remain non responders and don't develop adequate antibody titre essential for protection against hepatitis $B$ virus. This study is therefore designed to estimate the anti HBs titre among the medical students, who have completed three doses of hepatitis $B$ vaccine. Objectives: To determine the serum anti HBs antibodies among the outgoing final year MBBS students who have received complete 03 doses of hepatitis B vaccine. Study Design: Descriptive cross sectional study. Place and Duration: This study was conducted from November 2010 to December 2015 at Biochemistry department Punjab Medical College in collaboration with Nawaz Medicare Hospital Faisalabad. Material and Methods: Two hundred and fifty nine female medical (MBBS) students from outgoing classes during the period of November 2010 to December 2015 were enrolled in this study. All subjects were at the age of 22-24 years at the time of sampling. Each received 03 doses of injection Engerix $B, 10$ $\mathrm{mcg} / 0.5 \mathrm{ml}$ each in a schedule of $0,01,06$ months since the last 05 years. The blood samples were allowed to clot and serum was separated. The anti HBs and HBsAg were determined by $3^{\text {rd }}$ generation ELISA method. Results: A total 259 female medical students from outgoing final year MBBS classes were enrolled in this study. Among these subjects $48(18.5 \%)$ had serum anti HBs levels < $10 \mathrm{IU} / \mathrm{L}, 77$ subjects (29.7\%) have levels $10-20 \mathrm{IU} / \mathrm{L}, 116$ subjects (44.8 \%) have serum levels $21-100 \mathrm{IU} / \mathrm{L}$, while 18 subjects $(10 \%)$ have $>100 \mathrm{IU} / \mathrm{L}$ serum anti HBs levels. Conclusion: The incidence of non responders and poor responders is higher among the vaccinees in this study as compared to foreign studies after five years of Hepatitis $B$ vaccination.

Key words: Inj. Engerix B, Anti HBs, HBsAg, Non Responders, Poor Responders, Adequate Responders, Good Responders.

Article Citation: Ashraf N, Hussain MU, Qamar I, Ashraf M. Anti HBS titre; among outgoing final year MBBS students. Professional Med J 2017;24(8):1167-1169.

DOI: 10.17957/TPMJ/17.4086

\section{INTRODUCTION}

The infection caused by Hepatitis B virus is one of the commonest infective liver diseases all over the world. ${ }^{1}$ It is caused by a small DNA virus which is the member of the Hepadnviridas family. ${ }^{2}$ The virus directly enters from the carrier to recipient through blood products or contaminated pricking instruments. ${ }^{3}$ The disease manifests itself as chronic hepatitis, cirrhosis and hepatocellular carcinoma. ${ }^{4}$ The health care workers and doctors are at high risk to acquire this infection. ${ }^{5}$ For prevention of disease HBV vaccine is available and is quite effective. ${ }^{6}$ Prior to admission in medical colleges of Pakistan the complete course of HBV vaccination is mandatory. The immune response varies from individual to individual. ${ }^{7}$ The studies show that the immune response is better in early ages and poor in old ages. ${ }^{8}$ The response to hepatitis B virus vaccination is evaluated by measuring the titer of anti HBs in the serum of the vaccines. ${ }^{9}$ The minimum protective levels of serum anti HBs is $10 \mathrm{IU} / \mathrm{L}$ below which the vaccinee is declared as non responder. ${ }^{10}$ The studies show that the titre of anti HBs progressively fall with the advancement of age..$^{11}$ It is recommended that if the anti HBs titre after completion of the vaccination course is below $10 \mathrm{IU} / \mathrm{L}$, the minimum protected value, the vaccinee should be revaccinated by double than the previous doses. ${ }^{12}$ The immune response 
to $\mathrm{HBV}$ vaccination is also affected by gender. ${ }^{13}$ This study was therefore designed to evaluate the serum titre of anti HBs among the outgoing female students of MBBS final year classes, ages 2225 years at Punjab Medical College Faisalabad, who are at risk of maximum exposure to infection during house job period.

\section{MATERIAL AND METHODS}

\section{Subjects}

A total 259 female MBBS Students of ages 2125 years from outgoing MBBS classes of Punjab Medical College Faisalabad Year 2010-2014 were enrolled in this study according to following criteria.

1. All received HBV vaccine, inj. Engerix $B(10$ $\mathrm{mcg} / 0.5 \mathrm{ml}$ ) intramuscularly 04-05 year before sampling under schedule 0, 01, 06 monthly doses.

2. All were HBsAg negative at the time of sampling.

\section{Blood Sampling}

From anticubital vein $03 \mathrm{ml}$ blood was drawn using disposable syringe. Blood was allowed to clot for 30 minutes, centrifuged at 3000 rpm for 05 minutes, and sera were separated for analysis of HBsAg and anti HBs levels.

\section{Estimation}

Serum HBsAg and Anti HBs titre was determined by improved ELISA method. ${ }^{14}$

\section{RESULTS}

The anti HBs titre was determined in all 259 samples which were non reactive for HBsAg. The anti HBs titre was less than $10 \mathrm{IU} / \mathrm{L}$ among $48(18.5 \%)$ subjects and these were considered as non responders. Seventy seven vaccines (29.7\%) have anti HBs level 10-20 IU/L and were considered as weak responders One hundred \& sixteen subjects $(44.8 \%)$ have anti HBs titre between 21-100 IU/L and were considered as adequate responders. While only 18 (10\%) among 259 subjects had anti HBs level above $100 \mathrm{IU} / \mathrm{L}$ and they were considered as good responders.

\begin{tabular}{|c|c|c|c|}
\hline $\begin{array}{c}\text { Anti HBs } \\
\text { Titre }\end{array}$ & $\begin{array}{c}\text { No. of } \\
\text { Subjects }\end{array}$ & $\begin{array}{c}\text { Population } \\
\text { Percentage }\end{array}$ & Remarks \\
\hline$<10 \mathrm{IU} / \mathrm{L}$ & $48 / 259$ & $18.5 \%$ & $\begin{array}{c}\text { Non } \\
\text { Responders }\end{array}$ \\
\hline $10-20 \mathrm{IU} / \mathrm{L}$ & $77 / 259$ & $29.7 \%$ & $\begin{array}{c}\text { Weak } \\
\text { Responders }\end{array}$ \\
\hline $21-100 \mathrm{IU} / \mathrm{L}$ & $116 / 259$ & $44.8 \%$ & $\begin{array}{c}\text { Adequate } \\
\text { Responders }\end{array}$ \\
\hline$>100 \mathrm{IU} / \mathrm{L}$ & $18 / 259$ & $10 \%$ & $\begin{array}{c}\text { Good } \\
\text { Responders }\end{array}$ \\
\hline
\end{tabular}

\section{DISCUSSION}

The response to HBV vaccination among vaccines in the study was assessed by serum anti HBs level. A large population $48.2 \%$ in this study either belongs to non responders $18.5 \%$ (48/259) and or poor responders $29.7 \%$ (77/259). The adequate responders were $44.8 \%(116 / 259)$ while the good responders were only $10 \%, 18$ out of 259 subjects.

In this study the generalized response to HBV vaccine was poor as compared to the foreign studies. ${ }^{15}$ The response to vaccine varies with age and gender. In this study all subjects were female between 22-25 years. The time of analysis since completion of vaccine is also a factor which affects the anti HBs titre. ${ }^{16}$ All subjects in this study were vaccinated 04-05 years prior to analysis. The variation in vaccine brand and manufacturing company is also one of the causes of differences in response. ${ }^{17}$ In this study all subjects were vaccinated by Inj. Engerix B $10 \mathrm{mcg} / 0.5 \mathrm{ml}$ ampoule, which is a recommended dose up to the age of 19 years. The age of all study subjects at the time of vaccination was 17-19 years. The low response to vaccine in this population may be due to racial differences or poor maintenance of temperature during transport and storage of the vaccine.

\section{SUGGESTIONS}

It is suggested that for our population a booster dose should be given 05 year after the primary 03 dose vaccinations and the response may be evaluated 06 months after the booster dose. Secondly the available vaccine from the stores should be checked and analyzed for the desired titre of HBV levels. A comparison should be done, 
designing a study at these ages 17-19 years by dividing the subjects into two groups one receiving $10 \mathrm{mcg} / 0.5 \mathrm{ml}$ and the second receiving $20 \mathrm{mcg} / 1 \mathrm{ml}$, a normal adult dose.

Copyright@ 25 June, 2017.

\section{REFERENCES}

1. GBD, Global burden of disease study. 2015: Lancet, 388 (10053): 1545-1602.

2. Liang T. J: Hepatitis B: The virus and disease. Hematology 2009 May; 49 (5 Suppl).

3. [9] Lewis JD, Enfield KB, SifriCD. Hepatitis $\mathbf{B}$ in healthcare workers: Transmission events and guidance for management. World J Hepatol 2015; 7(3): 488-97.

4. El-serag Hb, Rudolph KL. Hepatocellular carcinoma; epidemiology and molecular carcinogenesis. Gastroenterology 2007. 132 (7); 2557-76.

5. A. de Schryver, B. Claesen, A. Meheus, M. van Sprundel, and G. Francois, "Eurepean survey of hepatitis B vaccination policies for healthcare workers," European journal of Public health, Vol. 21, no. 3, pp. 338-343, 2011.

6. F. H. Su, F. Y. Chu, C. H. Bai et al, "Efficacy of hepatitis $B$ vaccine boosters among neonatally vaccinated university freshmen in Taiwan," Jornal of Hepatology, Vol. 58, no 7, pp. 684-689, 2013.

7. M. A. Riva, F. Madotto, S. Conti, et al., "Hepatitis B vaccination coverage and booster dose: results from a survey onhealthcare students," Giornal Italiano di Medicina del Lavoro ed Ergonomia, vol. 34, no. 3, supplement, pp. 283-285. 2012.

8. Fisman, D. N., Agrawal, D. \& Leder, K. The effect of age in immunologic response to recombinant hepatitis $B$ vaccine: a meta-analysis. Clinical infectious diseases: an official publication of the Infectious Diseases Society of America 35, 1368-1375, doi; 10.1086/344271 (2002).

9. M. S. Sacchetto S. S. Barros, A. Araripe Tde, A. M. Silva, S.K. Faustion, and J. M. da Silva, "Hepatitis B : Knowledge, vaccine situation and seroconversion of dentistry students of a public university," Hepatitis Monthly, Vol. 13, no. 10, Article ID E13670,2013.

10. Chiara F, Bartolucci GB, Cattai M, Piazza A, Nicolli A, Buja $A$, Trevisana. Hep [atitisB vaccination of adolescents: significance of non-protective antibodies. Vaccine 2013; 32(1):62-8.

11. Coppola N, Coevino AR, De Pascalis S, at all. The longterm immunogenicity of recombinant hepatitis $B$ virus (HBV) vaccine: contribution of universal HBV vaccination in Ltaly. BMC Infect Dis 2015; 15:149.

12. C. C. Lin, C. K. Chang Y. L. Huang, and H. F. Tseng, "Low seroprevalence of heoatitis B surface antibody among nursing students in Taiwan: an implication for boosting," Vaccine, Vol 25, no. 51, pp. 8508-8511, 2007.

13. Stroffolini T, Guadagnino V, Caroleo B, at all. Longterm immunogenicity of hepatitis $B$ vaccination in children and adolescents in a sothern Italian town. Onfection 2012; 40(3): 299-302.

14. Wolters $G$, Nelissen $P$ and Kuijpers improved ELISA for HBsAg. J. Virus Method 1985 April; 10 (4); 299-305.

15. Bonanni $P$, BonaccorsiG. Vaccination against hepatitis B in health care workers. Vaccine $2001 ; 19(17-19)$ : 2389-94.

16. Gabutti A, L Romano, Blanc P, at all. Long-term immunogenicity of hepatitis $B$ vaccination in a cohort of Italian healthy adolescents. Vaccine 2007; 25:3129-32.

17. Nejad H. N.; Ghorbani G.; Razaghi , R. Akbari, H. Comparison of two recombinant hepatitis $B$ vaccines: Hepatitis Monthly 2009 Vol. 9 no. 3. pp. 201-205.

\section{AUTHORSHIP AND CONTRIBUTION DECLARATION}

\begin{tabular}{|c|l|l|l|}
\hline Sr. \# & \multicolumn{1}{|c|}{ Author-s Full Name } & \multicolumn{1}{|c|}{ Contribution to the paper } & Author=s Signature \\
\hline 1 & Nahdia Ashraf & Main Research Conductor \\
\hline 2 & Muhammad Usman Hussain & Co-worker in research \\
3 & Iqra Qamar & Co-worker in research \\
4 & Muhammad Ashraf & Supervisor & \\
\hline
\end{tabular}

